\title{
Monitoring of Insecticide Resistance and Exploring the Presence of Virus in Field Populations of Culex gelidus at Thiruvarur District of Tamil Nadu, India
}

\author{
Rajalakshmi Anbalagan', Arpita Shukla', Vimala Subramanian ${ }^{3}, \underline{\text { PK Srivastava }}^{4}$, \\ layalakshmi Krishnan ${ }^{5}$ \\ 1,2,5 Department of Life Sciences, Central University of Tamil Nadu, Thiruvarur, Tamil Nadu, India. \\ ${ }^{3}$ Department of Epidemiology and Public Health, Central University of Tamil Nadu, Thriuvarur, Tamil Nadu, India. \\ ${ }^{4}$ Former Joint Director, National Vector Borne Disease Control Programme, Delhi, India.
}

DOI: https://doi.org/10.24321/0019.5138.202177

\section{I $\quad \mathbf{N} \quad \mathbf{F} \quad \mathbf{O}$}

\section{Corresponding Author:}

Jayalakshmi Krishnan, Department of Life Sciences, Central University of Tamil Nadu, Thiruvarur, Tamil Nadu, India.

E-mail Id:

jayalakshmi@cutn.ac.in

Orcid Id:

https://orcid.org/0000-0003-3098-5755

How to cite this article:

Anbalagan R, Shukla A, Subramanian V, Srivastava PK, Krishnan J. Monitoring of Insecticide Resistance and Exploring the Presence of Virus in Field Populations of Culex gelidus at Thiruvarur District of Tamil Nadu, India. J Commun Dis. 2021;53(4):76-83.

Date of Submission: 2021-11-12

Date of Acceptance: 2021-12-23

\section{$\begin{array}{llllllll}\mathbf{A} & \mathbf{B} & \mathbf{S} & \mathbf{T} & \mathbf{R} & \mathbf{A} & \mathbf{C} & \mathbf{T}\end{array}$}

Introduction: The introduction of potent synthetic insecticides into public health programmes has since beginning posed the challenge of development of resistance among the insect vectors against the insecticides. Culex (CX.) gelidus is one of the vectors of JE which is abundantly found in southern India. Its breeding habitats are similar to the vishnui subgroup of Culex mosquitoes, the major vectors for transmission of JE. The present study was aimed to assess the susceptibility status of adult Culex (Cx.) gelidus, to insecticides, namely DDT (Dichlorodiphenyltrichloroethane), Deltamethrin, and Malathion.

Method: The field-collected mosquito larvae from ten villages of Thiruvarur district from December 2018 to May 2019 were reared in the laboratory until F1 generation and the emerged adults identified as $C x$. gelidus were exposed to insecticide-impregnated papers supplied through World Health Organization (WHO). The adult susceptibility tests were carried out as per the protocol of WHO. Further, an attempt was made to check the presence of JE virus in $C x$. gelidus and the virus detection was done by RT-PCR.

Results: The results indicated that the adult $C x$. gelidus populations were susceptible to DDT, whereas they were resistant to Malathion and Deltamethrin. The possible reason of DDT susceptibility may be that DDT has not been used in Tamil Nadu since the year 1980 (about 40 years).

Conclusion: JE virus was not detected in the tested mosquitoes. The study suggests that insecticide resistance monitoring from time to time is required to facilitate vector control programmes in focusing on appropriate vector control measures.

Keywords: $C x$. gelidus, DDT, Deltamethrin, Malathion, Thiruvarur, WHO Susceptibility Test 


\section{Introduction}

Japanese encephalitis (JE) is a vector-borne viral infection, transmitted by mosquitoes. Japanese encephalitis virus (JEV), a single-stranded RNA genome of about $11 \mathrm{~kb}$ in length, is a member of the family (Flaviviridae), genus (Flavivirus). ${ }^{1}$ JEV was first isolated from the brain of the foetal human encephalitis case in Tokyo in $1934 .^{2}$

\section{Disease Burden}

It has been reported from Eastern Asia, Southeast Asia, Northern Australia and Southern Asia.The countries that have reported JE are Bangladesh, Nepal, Sri Lanka, Thailand and Timor-Leste in South East Asia (SEA) Region and Malaysia, Indonesia, Philippines Cambodia, Vietnam, Laos, Fiji, China and Japan in Western Pacific Region..$^{3-9}$ In India, JE was first recognised to occur in Tamil Nadu in 1955, though, serological evidence for its prevalence was recorded in $1952 .{ }^{10} \mathrm{JE}$ in India is reported under the umbrella of Acute Encephalitis Syndrome (AES) which has been reported regularly from Andhra Pradesh, Assam, Bihar, Delhi, Goa, Haryana, Jharkhand, Karnataka, Kerala, Maharashtra, Manipur, Nagaland, Tamil Nadu, Uttar Pradesh, and West Bengal.

$C x$. tritaeniorhynchus, $C x$. vishnui, $C x$. pseudovishnui, and $C x$. bitaeniorhynchus under the subgroup of $C x$. vishnui are important vectors for disease transmission. Though the JE virus has been isolated from 30 species of mosquitoes belonging to 5 genera viz., Culex, Anopheles, Aedes, Mansonia and Armegeres in India, viruses have been isolated from 17 species. ${ }^{11-17} \mathrm{Cx}$. gelidus is reported to play a significant role in outbreaks, in addition to $C x$. tritaeniorhynchus, $C x$. vishnui, and Cx.pseudovishnui ${ }^{18-20}$

The study on mosquito abundance, pig sero-positivity and human JEV cases indicated a strong correlation with the presence of $C x$.tritaeniorhynchus and $C x$. gelidus in Sibsagar and Kamrup districts of Assam, respectively. ${ }^{21}$ Natural vertical transmission of $C x$. gelidus was also documented from Madurai, Coimbatore, and Cuddalore districts of Tamil Nadu. ${ }^{22-24} \mathrm{An}$ increase in the population of $\mathrm{Cx}$. gelidus was recorded in Thanjavur district which used to be less in earlier years. This study points out the exploration of $C x$. gelidus both for its susceptibility to insecticides and presence of virus in Thiruvaur district of Tamil Nadu, where rice cultivation is carried out. Cx. gelidus breeds in rice fields in addition to polluted and dirty water, ${ }^{25}$ since Thiruvarur harbours a variety of such breeding grounds, the possibility of an abundance of $C x$. gelidus in the district is high.

Vector control and reduction in human-vector contact by reducing the vector population have been the strategic component in the prevention and control of JE. Mosquitoes are also exposed to the insecticide used for elimination or control of other vector-borne diseases under the programme in addition to the insecticides used for agricultural purposes. The insecticide resistance monitoring (IRM) among vector mosquitoes has been emphasised in the Global vector control response (GVCR). ${ }^{26}$ Since $C x$. gelidus is a known secondary vector in various districts of Tamil Nadu, ${ }^{22-24}$ the virus isolation was also explored among the field caught mosquitoes along with resistance monitoring, so that, the current insecticide resistance and presence of circulating virus among this vector species if any, may be evidenced to facilitate the public health programme for the selection of appropriate and effective insecticide to be used under the vector control programme. The prevalence of $C x$. gelidus though reported to be high in southern India, no study has been reported on the insecticide susceptibility status of $C x$. gelidus in Thiruvarur district of Tamil Nadu. Considering the significance of IRM for JE vectors, the present study was undertaken to monitor the insecticide susceptibility status of $C x$. gelidus populations in Thiruvarur district.

\section{Material and Method}

Since this study involves mosquitoes, it does not require any ethical committee approval.

\section{Study Area and Period of Study}

The study was performed in Thiruvarur district. It covers an area of $2374 \mathrm{sq}$. km. It lying between $10^{\circ} 20^{\prime}$ and $11^{\circ} 07^{\prime}$ North latitude and $79^{\circ} 15^{\prime}$ and $79^{\circ} 45^{\prime}$ East longitude. ${ }^{27}$ Agriculture is the principal occupation of the district. The average annual rainfall in Thiruvarur District is $1173 \mathrm{~mm}$. It has a tropical climate, and the average temperature is $28.6^{\circ} \mathrm{C}$. The temperature is high in May (around $35.9^{\circ} \mathrm{C}$ ) and is low in January (around $21.3^{\circ} \mathrm{C}$ ). ${ }^{28}$ The study was undertaken from December 2018 to May 2019.

\section{Sample Collection}

Mosquito larvae were collected by dipping and pipetting methods from ten different pools of rural areas of the district Thiruvarur. The location of the sites using software ArcGIS 10.4 is shown in Figure 1. The mosquito larvae and pupae were collected from different sites of Thiruvarur district by dipping and pipetting methods (Figure 2a). ${ }^{29}$ The collected larvae and pupae were transferred into labelled plastic containers and transported to the Vector Biology Research Laboratory of the Department of Life Sciences, Central University of Tamil Nadu, Thiruvarur.

\section{Rearing and Identification}

The temperature between $25^{\circ} \mathrm{C}-28^{\circ} \mathrm{C}$ and relative humidity between $80 \%-90 \%$ were maintained in the laboratory. After emergence, the adult mosquitoes were identified morphologically according to the key of "A catalogue of Indian mosquitoes" from International Journal of Mosquito (2015). ${ }^{30}$ 


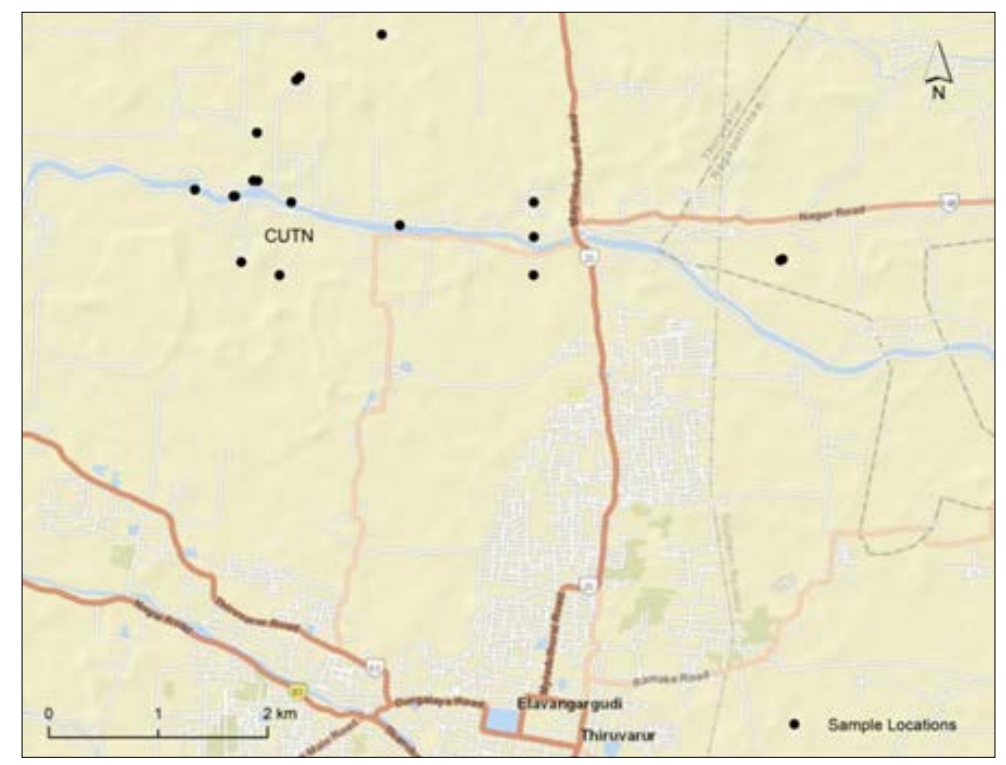

Figure I.GPS Co-ordinates of Various Locations at Thriuvarur district, Tamil Nadu, India

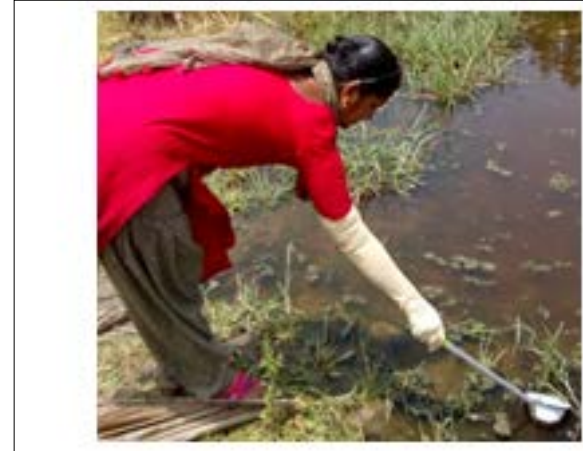

a. Sample Collection

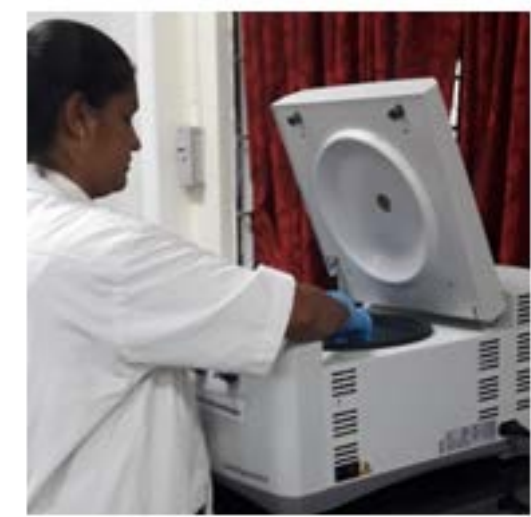

c. RNA Extraction

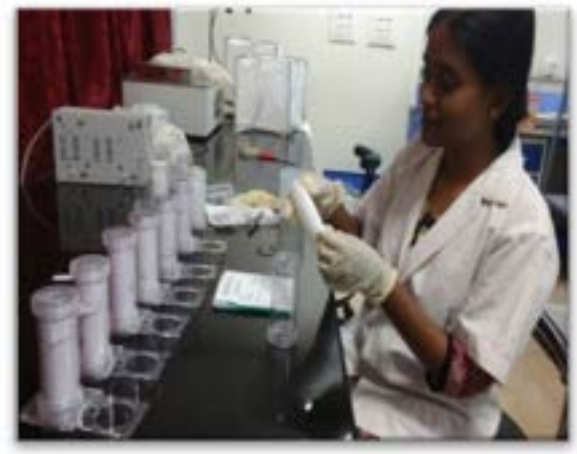

b. Insecticide Test

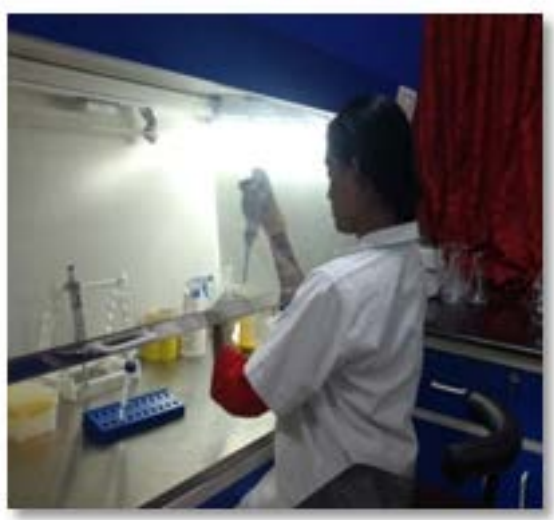

d. Sample Processing

Figure 2.Surveillance and Sample Processing Images

\section{Susceptibility Test of $C x$. gelidus}

Two to three days old laboratory hatched female mosquitoes of F1 generation were used for the insecticide susceptibility bioassay (Figure 2b). The susceptibility tests were performed using WHO supplied kits. The non-blood fed mosquitoes were exposed to DDT (4\%), Deltamethrin (0.05\%), and
Malathion (5\%). A total of 80 mosquitoes were exposed to insecticide-impregnated papers (4 replicates of 20 mosquitoes each). The control tests were also carried out using 40 mosquitoes exposed to control papers ( 2 replicates of 20 mosquitoes each). After one hour, the mosquitoes were transferred from exposure tubes to holding tubes 
and mortality was observed after one hour and 24 hours. The temperature and relative humidity were maintained throughout the test and exposure period.

The knockdown rate (KDR) was calculated by observing the number of knocked-down mosquitoes after 10, 20, 30, 40,50 , and 60 min during the hour-long exposure period.

\section{RNA Extraction and Reverse Transcription}

A pool of mosquito samples was homogenised to extract RNA using Trizol method, out of which $25 \mathrm{mg}$ of tissue was used for desirable yield before performing the experiments. ${ }^{31}$ The gel tank, the beakers, and micro tips were soaked in $0.1 \%$ DEPC water overnight and then autoclaved. Then the $25 \mathrm{mg}$ of tissue was homogenised thoroughly with $500 \mu \mathrm{l}$ of Trizol and kept for 2 days of incubation at $-80^{\circ} \mathrm{C}$. The samples were then processed by adding $100 \mu \mathrm{l}$ of chloroform and centrifuged at $12,000 \mathrm{rpm}$ for $15 \mathrm{~min}$ at $4^{\circ} \mathrm{C}$. The supernatant containing RNA was aspirated from the tube and mixed with $250 \mu$ l of isopropanol with a slight shack and kept for $10 \mathrm{~min}$ at room temperature. Then the samples were centrifuged at $12,000 \mathrm{rpm}$ for $15 \mathrm{~min}$ at $4^{\circ} \mathrm{C}$. The pellet of RNA was washed with $75 \%$ of ice-cold ethanol and again centrifuged at $12,000 \mathrm{rpm}$ for $1 \mathrm{~min}$ at $4^{\circ} \mathrm{C}$. Finally, the samples were allowed to air dry for $20 \mathrm{~min}$ and re-suspended with $30 \mu \mathrm{l}$ of RNase free water as shown in Figures 2(c) and 2(d). Bio-spectrometer (Eppendorf, Germany) was used to measure the ratio of absorbance at 260/280nm to assess the purity of RNA sample (ratio of $\sim 2$ is pure for RNA) and sample concentration was noted. Agarose gel electrophoresis was used to visualise the RNA band. As a next step, the reverse transcription was carried out from the RNA sample, according to the manual of cDNA synthesis kit (Prime Script ${ }^{\text {TM }}$ RT Reagent kit, Takara). cDNA was synthesised in a total volume of $10 \mu$ reaction mixture containing 5X Prime Script ( $2 \mu \mathrm{l})$, Prime Script RT Enzyme Mix $(0.5 \mu \mathrm{l})$, OligodT Primer $(0.5 \mu \mathrm{l})$, Random Hexamer $(0.5 \mu \mathrm{l})$, Total RNA $(2 \mu \mathrm{l})$ and RNase free water $(4.5 \mu \mathrm{l})$ as shown in Table 1 . The reaction mixture was incubated under the following conditions at $37^{\circ} \mathrm{C}$ for $15 \mathrm{~min}, 85^{\circ} \mathrm{C}$ for $5 \mathrm{sec}$ and $4^{\circ} \mathrm{C}$ for infinite $(\infty)$ time.

\section{Polymerase Chain Reaction for cDNA Amplification and Viral Detection}

The polymerase chain reaction (PCR) was performed using the kit method (Emerald Amp ${ }^{\circledR}$ GT PCR Master Mix, Takara). The following mixture was added in a PCR tube with a total volume of $50 \mu \mathrm{l}$ : Emerald Amp GT PCR Master mix ( $25 \mu \mathrm{l})$, JEV - prM Forward primer $0.2 \mu \mathrm{m}(2 \mu \mathrm{l})$, JEV - prM Reverse primer $0.2 \mu \mathrm{m}(2 \mu \mathrm{l})$, cDNA $(5 \mu \mathrm{l})$ and distilled water $(16 \mu \mathrm{l})$ were added as shown inFigure 2(d). Afterwards, 30 thermal cycles were performed, as from an initial denaturation at 94 for $10 \mathrm{~min}$, denaturation at $94^{\circ} \mathrm{C}$ for $60 \mathrm{sec}$, annealing at $60^{\circ} \mathrm{C}$ for $60 \mathrm{sec}$, extension at $72^{\circ} \mathrm{C}$ for $60 \mathrm{sec}$, final extension at $72^{\circ} \mathrm{C}$ for $10 \mathrm{~min}$ and cooling at $4^{\circ} \mathrm{C}$ for infinite $(\infty)$ time. The presence of cDNA was also checked by using Cytochorme $\mathrm{C}$ Oxidase subunit 1 (COX) primer as control as shown in Table 1. A total of 35thermal cycles were performed, beginning with an initial denaturation at $95^{\circ} \mathrm{C}$ for $5 \mathrm{~min}$, denaturation at $94^{\circ} \mathrm{C}$ for $40 \mathrm{sec}$, annealing at $45^{\circ} \mathrm{C}$ for $1 \mathrm{~min}$, extension at $72^{\circ} \mathrm{C}$ for $1 \mathrm{~min}$, final extension was carried out at $72^{\circ} \mathrm{C}$ for $5 \mathrm{~min}$ and samples were kept for cooling at $4^{\circ} \mathrm{C}$ for infinite $(\infty)$ time. The obtained PCR products were visualised by using $2 \%$ agarose gel and observed at a UV transilluminator (Bio pirnt - Gel Doc system ST4, Valleecder, France).

Table I.Primer Sequence Details

\begin{tabular}{|c|c|}
\hline Primer & Sequence $\mathbf{5}^{\prime}$ to $\mathbf{3}^{\prime}$ \\
\hline JEV- prM (Forward) & CGTTCTTCAAGTTTACAGCATTAGC \\
\hline JEV - prM (Reverse) & CCYRTGTTYCTGCCAAGCATCCAMCC \\
\hline COX 1 (Forward) & GGATTTGGAAATTGATTAGTTCCTT \\
\hline COX 1 (Reverse) & AAAAATTTTAATTCCAGTTGGAACAG \\
\hline
\end{tabular}

JEV-Japanese encephalitis virus; COX 1-Cytochrome c oxidase gene 1.

Table 2.Susceptibility Status of Cx. gelidus Adult Mosquitoes to Various Insecticides in Thiruvarur District, Tamil Nadu

\begin{tabular}{|c|c|c|c|c|c|c|c|}
\hline \multirow{2}{*}{$\begin{array}{l}\text { Name of } \\
\text { the Place }\end{array}$} & \multirow[t]{2}{*}{ Insecticide (\% Con.) } & \multicolumn{2}{|c|}{$\begin{array}{c}\text { No of Mosquitoes } \\
\text { Exposed }\end{array}$} & \multicolumn{2}{|c|}{$\begin{array}{l}\text { No of Mosquitoes } \\
\text { Dead (After } 24 \text { Hrs) }\end{array}$} & \multirow{2}{*}{$\begin{array}{c}\text { Observed } \\
\text { Mortality } \\
\text { (OM) \% }\end{array}$} & \multirow{2}{*}{$\begin{array}{l}\text { Status } \\
\text { (S/PR/R) }\end{array}$} \\
\hline & & $\mathbf{T}$ & C & $\mathbf{T}$ & C & & \\
\hline \multirow[b]{3}{*}{ Thiruvarur } & DDT (4) & 80 & 40 & 80 & 2 & 100 & Susceptible \\
\hline & Malathion (5) & 80 & 40 & 75 & 3 & 93 & Possible resistance \\
\hline & Deltamethrin (0.05) & 80 & 40 & 76 & 4 & 95 & Possible resistance \\
\hline
\end{tabular}

T- Test; C- control 


\section{Results}

\section{Adult Susceptibility Status}

The adult susceptibility bioassay results of $C x$. gelidus against three different insecticides are indicated in Table 2. There was no mortality observed in control tests, so Abbott's formula was not required to be applied. ${ }^{32}$ After 24 hours of exposure, the mortality of $100 \%$ was observed against $4 \%$ DDT indicating that $C x$. gelidus population in the study areas are highly susceptible to DDT. The mortality against $5 \%$ Malathion and $0.05 \%$ Deltamethrinwasrecorded as $93 \%$ and $95 \%$ respectively, which indicates possible resistance among $C x$. gelidus populations against Malathion and Deltamethrin. This is according to WHO criteria, the mortality range of $98-100 \%$ indicates susceptibility and less than $98 \%$ indicates the possible existence of resistance and requires further investigations.

The knockdown was observed at the KDT50 value of 36.6 mins for DDT, 23.0 mins for Deltamethrin and 43.73mins for Malathion. Knockdown Rate (KDR) of $C x$. gelidus against DDT, Deltamethrin, and Malathion for an exposure time of 1 hour at different time intervals are shown in Figures 3 and 4 and Table 3. Among all the three insecticides, it has been observed from the results that the time taken for $50 \%$ knockdown in $C x$. gelidus was found to be less in $0.05 \%$ Deltamethrin as compared with DDT and Malathion. Subsequently, the lowest KDT95 is observed in Deltamethrin, wher eas the highest value is observed in DDT (143.7 min) in Thiruvarur District, Tamil Nadu.

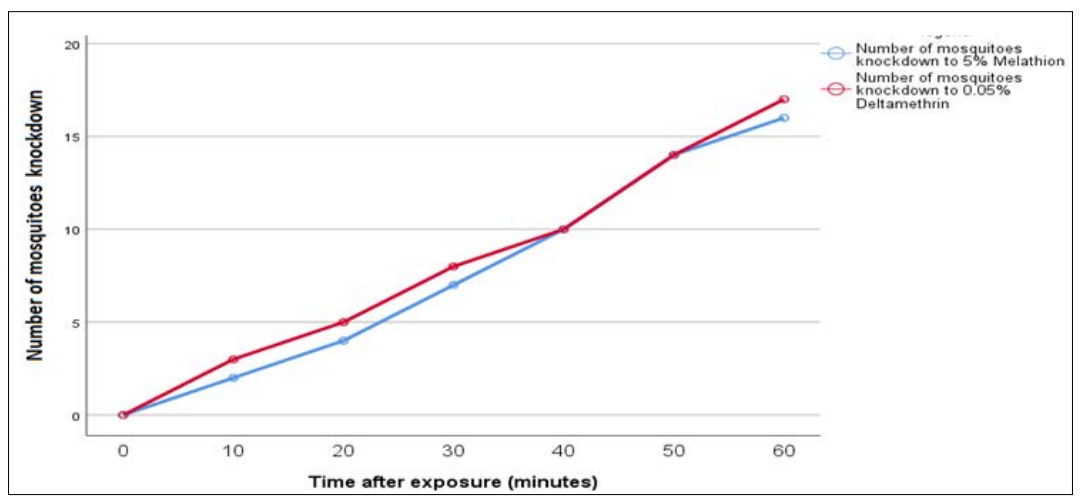

Figure 3.Graphical Representation depicts the Knockdown Rate of Malathion (5\%) and Deltamethrin (0.05\%) From the graph, it is clearly observed that the $C x$. gelidus population from the study area has a more knockdown sensitivity to Deltamethrin (0.05\%) as compared toMalathion (5\%)

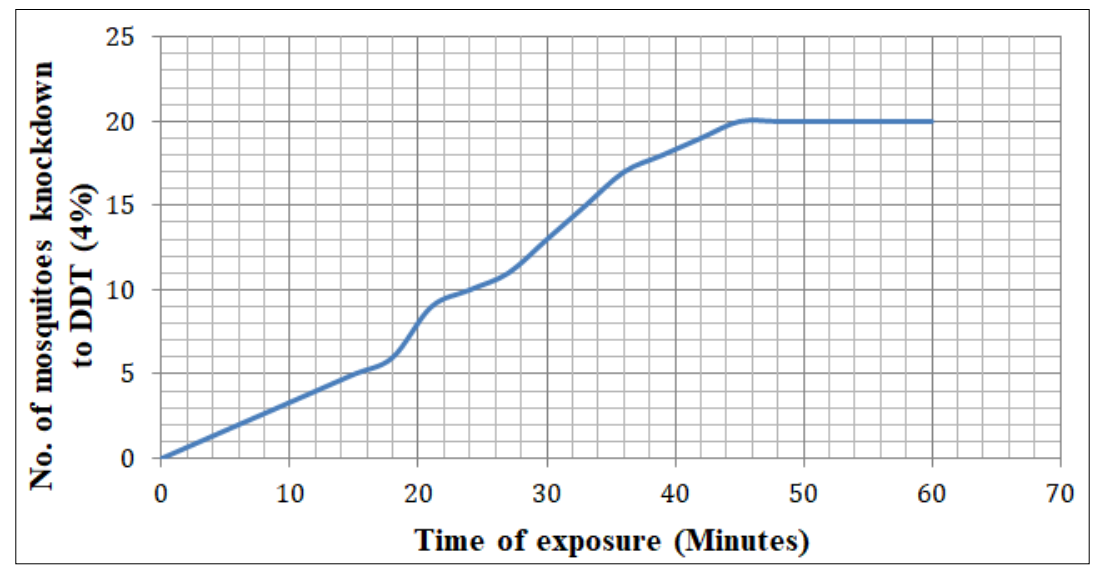

Figure 4.Knockdown Rate of DDT (4\%)

Cx. gelidus population from the study area showed a gradual increase in knockdown. Further, the population was found to be susceptible which showed a complete knockdown at $60 \mathrm{~min}$

Table 3.Knockdown Rate of Various Insecticides

\begin{tabular}{|c|c|c|c|c|}
\hline S. No. & District Name & Insecticide & $\left(\mathrm{KDT}_{50}\right) \mathrm{Min}$ & $\left(\mathrm{KDT}_{95}\right) \mathrm{Min}$ \\
\hline 1. & \multirow{3}{*}{ Thiruvarur } & DDT (4\%) & $36.6(26.8-45.8)$ & $143.7(87.2-496.9)$ \\
\hline 2. & & Malathion (5\%) & $43.73(35.4-49.0)$ & $90.6(72.6-171.8)$ \\
\hline 3. & & Deltamethrin $(0.05 \%)$ & $23.0(19.7-25.3)$ & $42.2(38.7-47.9)$ \\
\hline
\end{tabular}




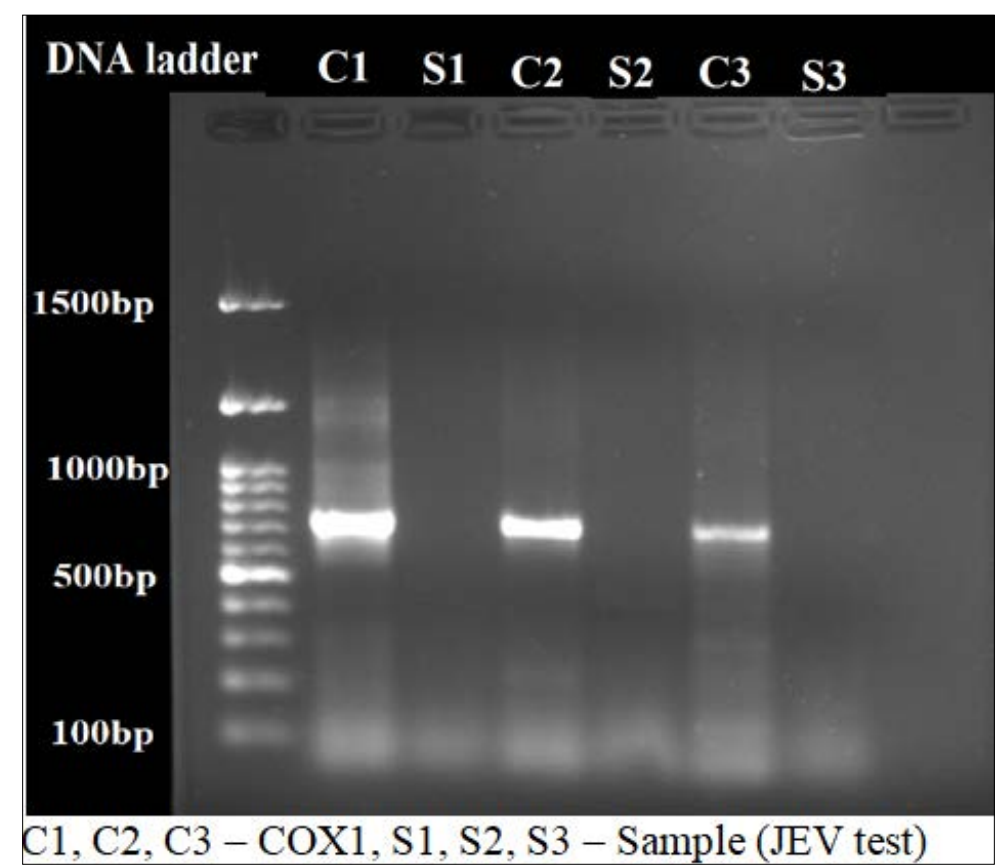

Figure 5.I.5\% Agarose Gel represents the RT-PCR Analysis of JEV and COX Gene Expressions in the Field Collected FI Generation of $C x$. gelidus

Lanes C1, C2, and C3 show the mRNA expression of mitochondrial Cytochrome c oxidase subunit 1 and this housekeeping gene was analysed to validate the cDNA. Here, the amplified COX1 gene product size is $758 \mathrm{bp}$ and it confirms the presence of cDNA. In parallel, the lanes of S1, S2, and S3 wereloaded with JEV tested study samples and it should be noted that there was no amplification observed. It indicates that the samples were not infected with JEV In addition to the susceptibility status, the JE viral detection was explored using RT-PCR technique in $C x$. gelidus to endorse the presence of JE virus in field-collected samples and depicts the representative agarose gel showing the level of expression of JEV in samples 1, 2, and 3. This analysis was performed to provide an extra arm to this study. In parallel, COX the housekeeping gene was also analysed (Figure 5, lane $\mathrm{C} 1, \mathrm{C2}$ and $\mathrm{C3}$ ) to validate the presence of CDNA and the gene expression. The obtained result reveals that the analysed mosquitoes are non-infected with JEV because there was an absence of expression in JEV analysed samples. More samples are needed to be analysed for further confirmation.

\section{Discussion}

Cx. gelidus is reported to be the predominant secondary vector of JE in peri-urban and rural areas of India. ${ }^{33}$ The present study was undertaken to assess the insecticide susceptibility status of $C x$. gelidus in Thiruvarur district of Tamil Nadu as no such information was available from this area. The mortality of $100 \%$ was observed against $4 \%$ DDT which indicates the susceptibility of $C x$. gelidus population to DDT, while the mortality of $93 \%$ against $5 \%$ Malathion and $95 \%$ against $0.05 \%$ Deltamethrin indicates the possible resistance among $C x$. gelidus populations against Malathion and Deltamethrin. This is according to WHO criteria, mortality range of $98-100 \%$ indicates the susceptibility and less than $98 \%$ indicates the possible existence of resistance.

Further, in the present study, it was found that KDT50 and KDT95 values for DDT are 36.6 and 143.7 min respectively, and for Deltamethrin, the lowest rates were observed ( 23 and 42 min respectively). In addition, the knockdown values for Malathion were also observed within the denoted time (43.73 and $90.6 \mathrm{~min}$, respectively). Among all the three insecticides, it has been observed that the $C x$. gelidus was sensitive to Deltamethrin. Although Deltamethrin showed the lowest knockdown values, the mortality rate is higher in DDT which indicates that the $C x$. gelidus is more susceptible to DDT as compared to Malathion and Deltamethrin. A similar observation was recorded in a study conducted at Sibasagar, Assam by Dhiman et al. In the study, it was found that the KDT50 and KDT95 values (47.81 and $304.97 \mathrm{~min}$, respectively) were highest for DDT, where as the lowest rates of knock down values were reported for Deltamethrin in Cx. gelidus (27.26 min). ${ }^{34}$

On the other hand, $C x$. quinquefasciatus is resistant to DDT and Malathion and $100 \%$ susceptible to Deltamethrin as shown in a study conducted at major filarial endemic districts (Chandauli and Varanasi) of Uttar Pradesh, North and army cantonments and neighbouring villages of Northeastern India. ${ }^{35,36}$ This indicates that at several places in India, the resistance status for various insecticides to different vector species or same species has been reported as varying.

In the present study, the possible resistance observed to Malathion and Deltamethrin can be correlated with the 
use of these insecticides in agricultural practices in the district. There are similar scientific reports of resistance in An. Culicifacies the malaria vector against Malathion and Deltamethrin in the Odisha state of India. ${ }^{37} \mathrm{Cx}$. gelidus has shown resistance to Deltamethrin and susceptibility to Malathion in a study undertaken in West Bengal, India. ${ }^{33}$ The reason for variation in the susceptibility status of same insecticides to same vectors at different places may be due to insecticide pressure but it needs further exploration of resistance mechanisms. Further, in our study, the virus could not be detected in mosquitoes for which more samples needed to be analysed but could not be done due to the limitation of field visits during COVID-19.

\section{Conclusion}

The present study concludes that $C x$. gelidus one of the JE vectors, was found to be susceptible to DDT whereas, possible resistance was noted against Malathion and Deltamethrin in Thiruvarur district of Tamil Nadu. The findings of the present study could be highly useful in the management of vector control targeting vectors like $C x$. gelidus. Further, viral detection in the $C x$. gelidus was investigated which revealed that the analysed mosquitoes were non-infected with JEV. However, more sampling and its analysis may facilitate in confirming the evidence of virus isolation from $C x$. gelidus.

\section{Acknowledgement}

The authors are thankful to the Department of Life Sciences, Central University of Tamil Nadu for providing supportthroughout the research work.

\section{Sources of Funding: None \\ Conflict of Interest: None}

\section{References}

1. Igarashi A, Tanka M, Morita A Takasu T, Ahmed A, Ahmed A,Akram DS, Waqar MA.Detection of West Nile and Japanese encephalitis viral genome sequences in cerebrospinal fluid from acute encephalitis cases in Karachi, Pakistan. Microbiollmmunol. 1994;38(10):82730. [PubMed] [Google Scholar]

2. Mitamura T, Kitaoka M, Watanabe M, Okuba K, Tenjin S, Yamada S, Mori K, Asada J. Study on Japanese encephalitis virus. Animal experiments and mosquito transmission experiments. Kansai lji. 1936;1:260-1.

3. Burke DS,Leake CJ. Japanese encephalitis. In: Monath TP,editor. The arboviruses: epidemiology and ecology. Florida: CRC Press, Boca Raton; 1988.p. 63-92.

4. Endy T,Nisalak A. Japanese encephalitis virus: ecology and epidemiology. In: Mackenzie JS, Barrett AD, Deubel $V$, editors. Japanese encephalitis and West Nile viruses. Springer, Berlin, Heidelberg;2002. p. 11-48. [Google Scholar]
5. Mackenzie JS, Williams DT,Smit DW. Japanese encephalitis virus: the geographic distribution, incidence and spread of a virus with a propensity to emerge in new areas. PerspectMed Virol. 2006;16:201-68. [Google Scholar]

6. Kuwata R, Torii S, Shimoda H, Supriyono S, Phichitraslip T, Prasertsincharoen N, Takemae H, Bautista RC, Ebora VD, Abella JA, Dargantes AP, Hadi UK, Setiyono A, Baltazar ET, Simborio LT, Agungpriyono S, Jittapalapong S, Rerkamnuaychoke W, Hondo E, Maeda K. Distribution of Japanese encephalitis virus, Japan and Southeast Asia, 2016-2018. Emerg Infect Dis. 2020 Jan;26(1):125. [PubMed] [Google Scholar]

7. van den Hurk AF, Pyke AT, Mackenzie JS, Hall-Mendelin S, Ritchie SA.Japanese encephalitis virus in Australia: From known known to known unknown. Trop Med Infect Dis.2019 Feb;4(1):38. [PubMed] [Google Scholar]

8. Yun SI, Lee YM. Japanese encephalitis: the virus and vaccines. Hum Vaccinlmmunother.2014;10(2):263-279. [PubMed] [Google Scholar]

9. Yoshii K. Epidemiology and pathological mechanisms of tick-borne encephalitis. J Vet Med Sci. 2019 Mar;81(3):343-7.[PubMed] [Google Scholar]

10. Work T,Shah K. Serological diagnosis of Japanese B type of encephalitis in North Arcotdistrict of Madras state, India, with Epidemiological Notes. Ind J Med Sci. 1956;10(8):582-92. [Google Scholar]

11. Pearce JC, Learoyd TP, Langendorf BJ, Logan JG.Japanese encephalitis: the vectors, ecology and potential for expansion. J Travel Med. 2018 May;25(Suppl_1):S16-26. [PubMed] [Google Scholar]

12. Su CL, Yang CF, Teng HJ, Lu LC, Lin C, Tsai KH, Chen YY, Chen LY, Chang SF, Shu PY. Molecular epidemiology of Japanese encephalitis virus in mosquitoes in Taiwan during 2005-2012.PLoSNegl Trop Dis.2014 Oct;8(10):e3122. [PubMed] [Google Scholar]

13. Gajanana A, Rajendran R, Samuel PP, Thenmozhi V, Tsai TF, Kimura-Kuroda J, Reuben R. Japanese encephalitis in south Arcot district, Tamil Nadu, India: a three-year longitudinal study of vector abundance and infection frequency. J Med Entomol.1997 Nov;34(6):651-9. [PubMed] [Google Scholar]

14. Lindahl JF, Ståhl K, Chirico J,Boqvist S, Thu HTV, Magnusson U. Circulation of Japanese encephalitis virus in pigs and mosquito vectors within Can Tho city, Vietnam. PLoSNegl Trop Dis.2013;7(4):e2153. [PubMed] [Google Scholar]

15. Seo HJ, Kim HC, Klein TA, Ramey AM, Lee JH, Kyung SG, Park JY, Cho YS, Cho IS, Yeh JY.Molecular detection andgenotyping ofJapanese encephalitis virus in mosquitoes during a 2010 outbreak in the Republic of Korea. PLoSOne. 2013;8(2):e55165. [PubMed] [Google Scholar]

16. Tao Z, Liu G, Wang M, Wang H, Lin X, Song L, Wang S, Wang 
H, Liu X, Cui N, Song Y, Xu A. Molecular epidemiology of Japanese encephalitis virus in mosquitoes during an outbreak in China 2013. Sci Rep. 2014 May;4(1):1-7. [PubMed] [Google Scholar]

17. Kanojia P. Ecological study on mosquito vectors of Japanese encephalitis virus in Bellary district, Karnataka. Indian J Med Res. 2007 Aug;126(2):152. [PubMed] [Google Scholar]

18. Ramesh D, Muniaraj M, Samuel PP, Thenmozhi V, Venkatesh A, Nagaraj J, Tyagi BK.Seasonal abundance \& role of predominant Japanese encephalitis vectors CulextritaeniorhynchusandCx. gelidus Theobald in Cuddalore district, Tamil Nadu. Indian J Med Res. 2015 Dec;142(Suppl 1):S23. [PubMed] [Google Scholar]

19. Arunachalam N, Murty US, Narahari D, Balasubramanian A, Samuel PP, Thenmozhi V, Paramasivan R, Rajendran $R$, Tyagi BK.Longitudinal studies of Japanese encephalitis virus infection in vector mosquitoes in Kurnool district, Andhra Pradesh, South India. J Med Entomol.2014 May;46(3):633-9. [PubMed] [Google Scholar]

20. Kanojia PC, Shetty PS, Geevarghese G. A long-term study on vector abundance \& seasonal prevalence in relation to the occurrence of Japanese encephalitis in Gorakhpur district, Uttar Pradesh. Indian J Med Res. 2003 Mar;117:104. [PubMed] [Google Scholar]

21. Boruah P, Baruah A, Barman B, Nath C, Hajong R, Naku N.Mosquito abundance and pig seropositivity as a correlate of Japanese encephalitis in human population in Assam, India. J Vector Borne Dis.2018 Oct-Dec;55(4):291S. [PubMed] [Google Scholar]

22. Kumar AN, Murugan K,Vincent CT, Madhiyazhagan $P$, Nataraj T, Shobana K. The distribution of Culexmosquitoes in Coimbatore, Tamil Nadu, India. J EntomolAcarol Res.2015;47(1):1-15. [Google Scholar]

23. Kabilan L, Rajendran R, Arunachalam N, Ramesh S, Srinivasan S, Samuel PP, Dash AP. Japanese encephalitis in India: an overview. Indian J Pediatr.2004 Jul;71(7):60915. [PubMed] [Google Scholar]

24. Mani TR, Rao CV, Rajendran R, Devaputra M, Prasanna Y, Hanumaiah, Gajanana A, Reuben R.Surveillance for Japanese encephalitis in villages near Madurai, Tamil Nadu, India. Trans R Soc Trop Med Hyg.1991 MarApr;85(2):287-91. [PubMed] [Google Scholar]

25. Samuel PP, Ramesh D, Mayilsamy M, Arunachalam N. Japanese encephalitis vectors in Thanjavur district, Tamil Nadu, India. Int J Fauna Biol.2015;2:28-32. [Google Scholar]

26. World Health Organization [Internet]. Neglected tropical diseases: Global Vector Control response 2017-2030; 2017 [cited 2021 Jan 15]. Available from: https://www. who.int/publications/i/item/9789241512978

27. National Informatics Centre [Internet]. Thiruvarur District; 2020 [cited 2021 Jan 15]. Available from: https://tiruvarur.nic.in/
28. Government of Tamil Nadu [Internet]. Thiruvarur district climate and rainfall; [cited 2021 Jan 15]. Available from: https://www.tn.gov.in/deptst/climateandrainfall.pdf

29. Brisco KK, Cornel AJ, Lee YJ, Mouatcho J, Leo Braack L. Comparing efficacy of a sweep net and a dip method for collection of mosquito larvae in large bodies of water in South Africa. F1000Res. 2016 Apr;5:713. [PubMed] [Google Scholar]

30. Tyagi B, Munirathinam A, Venkatesh A. A catalogue of Indian mosquitoes. Int J Mosq Res. 2015;2(2):50-97. [Google Scholar]

31. Kalaiarasu LP, Subramanian V, Boopathi Sowdharrajan $B$, Vellaichamy E.Insight into the anti-inflammatory mechanism of action of atrial natriuretic peptide, a heart derived peptide hormone: involvement of COX-2, MMPs, and NF-kB pathways. Int J Pept Res Ther.2016;22(4):45163. [Google Scholar]

32. World Health Organization. Test procedures for insecticide resistance monitoring in malaria vector mosquitoes. 2nded. 2016. [Google Scholar]

33. Saha P, Ballav S, Chatterjee M, Ganguly S, Sarker M, Biswas AK, Pramanik T, Basu N, Maji AK.The status of susceptibility of Japanese encephalitis vectors to insecticides in endemic areas of northern districts of West Bengal, India. Jpn J Infect Dis.2018 Mar;71(2):918. [PubMed] [Google Scholar]

34. Dhiman S, Rabha B, Talukdar PK, Das NG, Yadav K, Baruah I, Singh L, Veer V.DDT \&deltamethrin resistance status of known Japanese encephalitis vectors in Assam, India. Indian J Med Res. 2013 Dec;138(6):988-94. [PubMed] [Google Scholar]

35. Sarkar M, Bhattacharyya IK, Borkotoki A, Goswami D, Rabha B, Baruah I, Srivasatava RB. Insecticide resistance and detoxifying enzyme activity in the principal bancroftianfilariasis vector, Culexquinquefasciatus, in northeastern India. Med Vet Entomol. 2009 Jun;23(2):122-31. [PubMed] [Google Scholar]

36. Kumar K, Sharma AK, Kumar S, Patel S, Sarkar $\mathrm{M}$, Chauhan LS. Multiple insecticide resistance/ susceptibility status of Culex quinquefasciatus, principal vector of bancroftianfilariasis from filaria endemic areas of northern India. Asian Pac J Trop Med.2011 Jun;4(6):426-9. [PubMed] [Google Scholar]

37. Sahu S, Gunasekaran K, Vijayakumar T, Jambulingam P. Triple insecticide resistance in Anopheles culicifacies: a practical impediment for malaria control in Odisha State, India. Indian J Med Res. 2015 Dec;142(Suppl 1):S59. [PubMed] [Google Scholar] 